\title{
Who killed my dog? Use of forensic genetics to investigate an enigmatic case
}

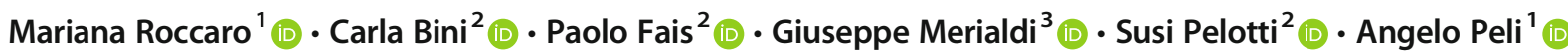

Received: 31 March 2020 / Accepted: 3 August 2020 / Published online: 11 August 2020

(C) The Author(s) 2020

\begin{abstract}
Genetic testing of animal biological material has become a valuable tool in forensic investigations, and it is successfully used to identify unknown crime perpetrators, to unmask food frauds, or to clarify cases of animal attacks on humans or other animals. When DNA profiling is not possible due to inadequate amounts of nuclear DNA, mitochondrial DNA (mtDNA) testing is the only viable alternative, as in the case of shed hair samples. In this case, a dog was allegedly killed by wild animals while being hosted in a boarding house. Extraneous hair fragments recovered from the dog's mouth and paws were subjected to genetic analysis: the cytochrome $b$ gene located on mtDNA was amplified and sequenced in order to determine the species responsible for the killing. The mtDNA analysis provided evidence that the dog was killed by other dogs, thus unmasking a false wild animal attack and putting the case in an entirely different perspective.
\end{abstract}

Keywords Forensic genetics $\cdot$ mtDNA $\cdot$ Cytochrome $b \cdot$ Hair $\cdot$ Dog $\cdot$ Animal attacks

\section{Introduction}

Genetic testing of animal biological material has become a valuable tool in civil and criminal forensic investigations [1-3]. Animals can help linking victims and/or suspects to a crime scene [4-7], but they can also be directly involved in an investigation either as victims or offenders, as in cases of property damage or attacks on humans or other animals [8-13].

Electronic supplementary material The online version of this article (https://doi.org/10.1007/s00414-020-02388-9) contains supplementary material, which is available to authorized users.

Mariana Roccaro

mariana.roccaro2@unibo.it

1 Department of Veterinary Medical Sciences, University of Bologna, Ozzano dell'Emilia, Italy

2 Department of Medical and Surgical Sciences, Unit of Legal Medicine, University of Bologna, Bologna, Italy

3 Istituto Zooprofilattico Sperimentale della Lombardia e dell'EmiliaRomagna “Bruno Ubertini”, Bologna Unit, Bologna, Italy
Genetic testing can be performed on a wide variety of biological materials, such as blood, faeces, urine, semen, bone, skin, hair, fur and other tissues.

Nuclear DNA testing allows individual identification through STR (short tandem repeat) or SNP (single nucleotide polymorphism) profiling [14-16]. However, if the amount and/or quality of nuclear DNA in the sample is inadequate, the more abundant and resistant mitochondrial DNA may be suitable for genetic analysis. This is the case with shed hair samples, which often do not contain follicular material [17-20].

MtDNA is primarily used for species identification by the analysis of the cytochrome $b$ gene $(C y t B)$, the most common locus on mtDNA used for species determination [21-25]. Other useful regions are the cytochrome oxidase subunit I gene (COI) and the $16 \mathrm{~S}$ ribosomal RNA gene [26-28].

MtDNA sequencing can also target the two hypervariable regions (HV1 and HV2) within the D-loop and several studies have been published on the canine mtDNA D-loop, although an exhaustive canine mtDNA population database is still unavailable [29-34]. However, the potential value of this method in forensic analysis can be considerable for the exclusion of an individual dog as a source of evidence $[19,30]$. 
In this case, we applied genetic analysis of $C y t B$ on animal hairs in order to determine the species of the animal(s) responsible for killing a dog.

\section{Case history}

An 8-year-old female Jack Russel Terrier hosted in a dog boarding house was found dead in the courtyard. The net of the kennel where the dog was held was broken, as if it had been pulled from the inside. The veterinarian who was called to the scene hypothesised that the cause of death was attributable to traumatic injuries inflicted by wild animals, such as foxes or nutrias. The tenant of the dog boarding house owned three Hovawart dogs.

The dog's carcass was left at ambient temperature (average daily temperature $7.0^{\circ} \mathrm{C}$ ) for $18-20 \mathrm{~h}$ and then stored at $18{ }^{\circ} \mathrm{C}$ pending post mortem examination, which was performed 1 month later at the diagnostic section of the Istituto Zooprofilattico Sperimentale of Lombardia and EmiliaRomagna located in Bologna.

Our team was contacted by the dog's owner in order to assist with the necropsy and to possibly identify the animal(s) responsible for the killing.

At the external inspection, the dog appeared in good nutritional condition.

The haircoat was blood-stained and 14 wounds, $7-10 \mathrm{~mm}$ in size, were observed in various areas of the body: one on the right side of the nape, one on the dorsal side of the neck and three more on the ventral side, one on the left shoulder, one on the left thorax and two more behind the costal arch, two on the right thigh and three in the inguinal region. These wounds were oval with sharp margins and were therefore attributed to bite marks (Fig. 1).

An additional and larger wound, $100 \mathrm{~mm}$ long and $25 \mathrm{~mm}$ wide, was observed in the lumbar region.

The inspection of the oral cavity revealed the presence of numerous hairs, caught between the teeth (Fig. 2); other hairs were entangled in the paws (Fig. 3). The length $(50-100 \mathrm{~mm}$ ) and colour (some light/fair, others dark) of the hairs, in addition to the unnatural location where they were found, were incompatible with those of the dog examined. These hairs were therefore sampled for genetic analysis.

When skinned, sub-dermal haemorrhages were observed behind the wounds, which extended to the muscles on the left side of the neck and the thorax, where the haemorrhagic infiltration was massive. Upon opening the abdomen and the thoracic cavity, a small amount of free blood was observed. Despite the poor state of preservation, all organs in the abdominal and thoracic cavity were found to be normal on gross observation. The abdominal wall was perforated at the wounds detected behind the costal arch. Similarly, the intercostal muscles and the pleura were perforated between the eight and the ninth rib. Moreover, the fifth rib was fractured. The signs of vital reactions in the affected tissues allowed to determine that the lesions observed where inflicted while the victim was still alive.

Fig. 1 Bite marks on the victim's right thigh

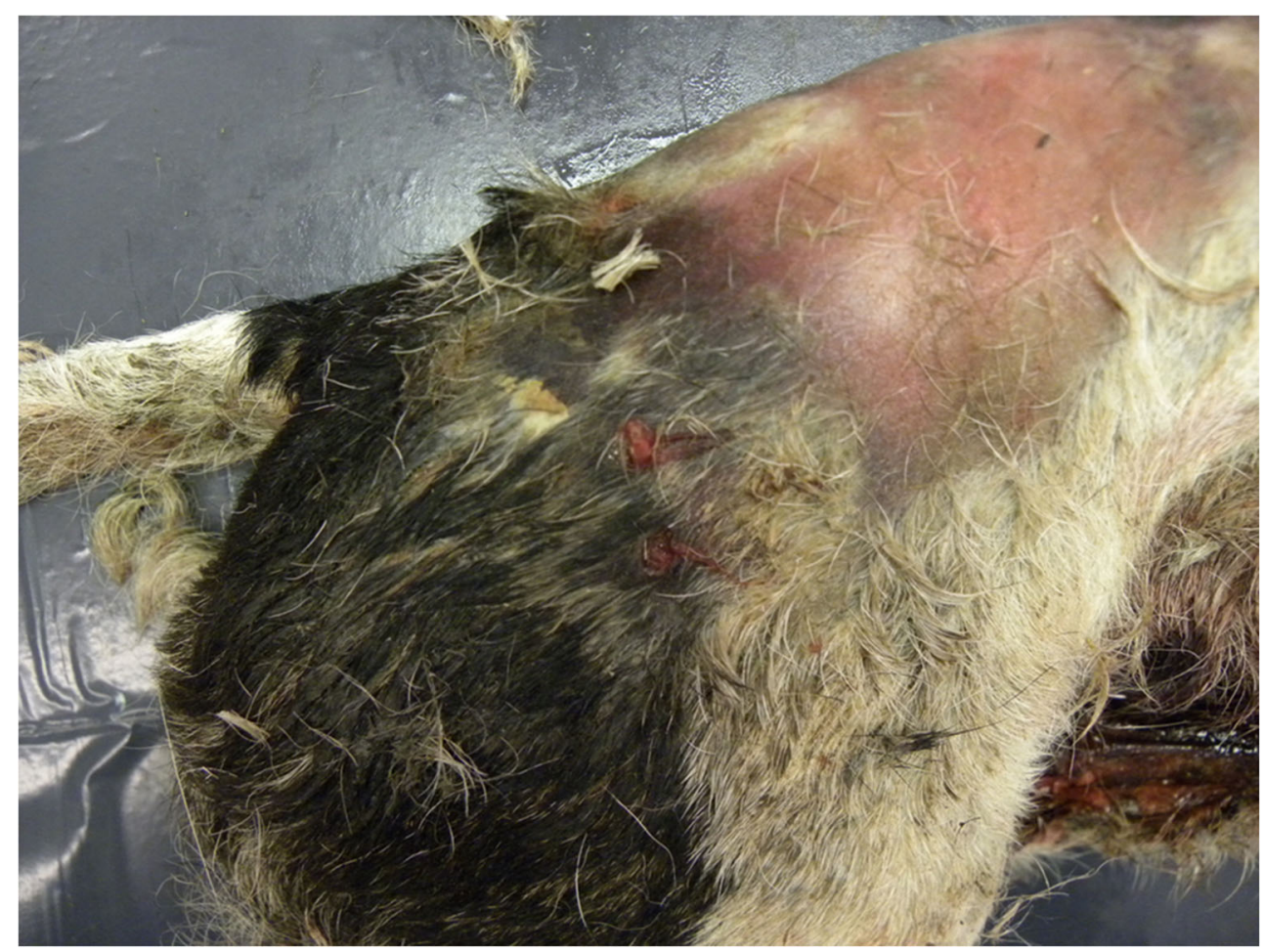




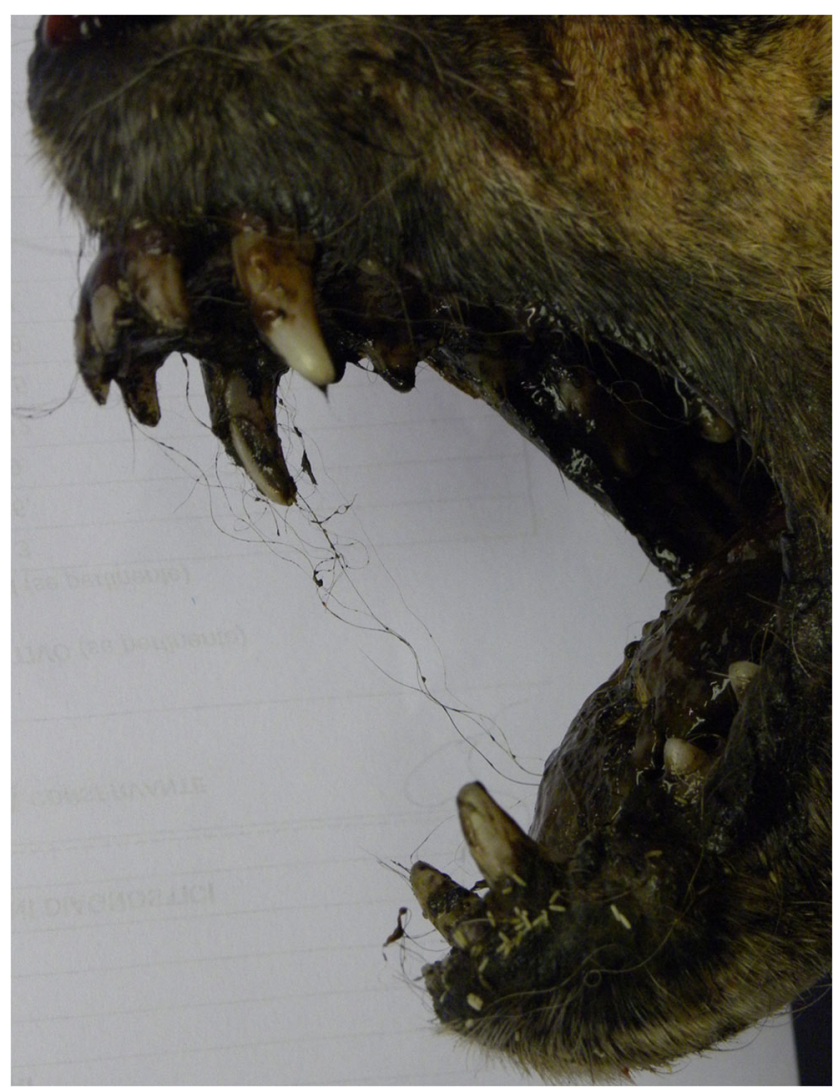

Fig. 2 Hairs caught between the victim's teeth

Cause of death was ascribed to a fatal pneumothorax resulting from multiple penetrating bite wounds to the thorax. The post mortem examination thus provided conclusive evidence of a fatal attack, perpetrated by one or more animals. The presence of numerous hairs, caught between the teeth and the paws of the victim, was indicative of a fight.

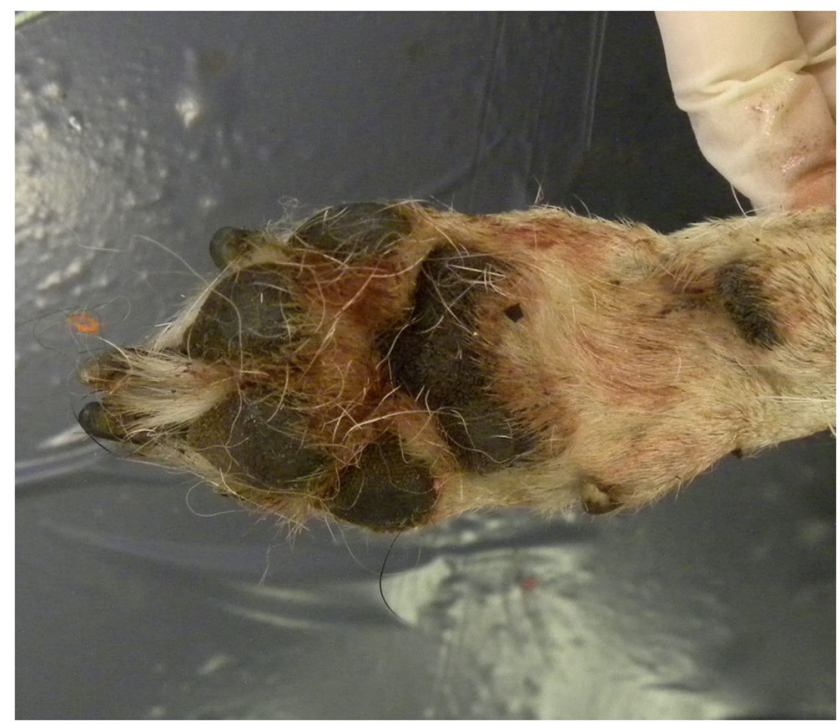

Fig. 3 Hairs entangled in the victim's right forepaw

\section{Materials and methods}

The DNA analysis was performed in an ISO 9001:2015 certified laboratory. The laboratory does not routinely conduct non-human DNA testing; for this casework, all the analyses were performed following the recommendations set out by the International Society for Forensic Genetics (ISFG) regarding the use of non-human DNA in forensic genetic investigations [35].

Hairs showing different characteristics were selected for the analysis; the longest and the most intact ones were preferred. Several fragments of four hair samples (three collected from the dog's mouth and one from the paw) were firstly decontaminated in order to eliminate any exogenous DNA by following the protocol of Jehaes et al. [36].

DNA was extracted using the QIAamp DNA Investigator kit (Qiagen) following the protocol of the manufacturer for the "Isolation of Total DNA from Nail Clippings and Hair" with an overnight incubation at $56^{\circ} \mathrm{C}$ and a final DNA elution in $20 \mu \mathrm{l}$ of buffer ATE.

The isolated DNA was analysed following the protocol of Hsieh et al. [22] to amplify the $C y t B$ gene region using the primers L14724 (5'-CGAAGCTTGATATGAAAAAC CATCGTTG-3') and H15149 (5'-AAACTGCAGCCCCT CAGA ATGATATTTGTCCTCA-3').

PCR amplification was performed in $25 \mu$ of reaction volume containing $2.5 \mu \mathrm{l}$ of 10X PCR of Buffer II, $1.5 \mathrm{mM}$ of $\mathrm{MgCl} 2,0.2 \mathrm{mM}$ of each dNTP, $0.25 \mu \mathrm{M}$ of each primer, $1.25 \mathrm{U}$ of AmpliTaq Gold DNA Polymerase (Thermofisher Scientific) and $10 \mu \mathrm{l}$ of template DNA. Amplification was conducted on a 9700 Thermal Cycler (Applied Biosystems) at the following conditions: $95{ }^{\circ} \mathrm{C}$ for $11 \mathrm{~min}, 35$ cycles of $94{ }^{\circ} \mathrm{C}$ for $30 \mathrm{~s}$, $50{ }^{\circ} \mathrm{C}$ for $45 \mathrm{~s}$ and $72{ }^{\circ} \mathrm{C}$ for $45 \mathrm{~s}$ and a final extension of $72{ }^{\circ} \mathrm{C}$ for $7 \mathrm{~min}$. PCR products were purified using the ExoSAP-IT PCR clean-up protocol (USB Corporation).

Cycle sequencing was performed using the Big Dye Terminator Cycle Sequencing Kit v.1.1 (Applied Biosystems) on a 9700 Thermal Cycler (Applied Biosystems) at the following conditions: $96{ }^{\circ} \mathrm{C}$ for $1 \mathrm{~min}$, 25 cycles of $96{ }^{\circ} \mathrm{C}$ for $45 \mathrm{~s}, 50{ }^{\circ} \mathrm{C}$ for $20 \mathrm{~s}$ and $72{ }^{\circ} \mathrm{C}$ for $4 \mathrm{~min}$. Forward and reverse sequences were obtained using both primers L14724 or H15149. The cycle sequencing reaction contained $3 \mu \mathrm{l}$ of purified PCR product, $2 \mu \mathrm{l}$ BDT v1.1 Ready Reaction Mix, $2 \mu$ BDT v1.1 5X Sequencing Buffer, $0.5 \mu \mathrm{M}$ sequencing primers and water grade to reach a total reaction volume of $20 \mu \mathrm{l}$.

PCR sequencing products were separated through CE using a POP4 polymer on ABI310 Genetic Analyzer (Applied Biosystems) and analysed by the Sequencing Analysis Software v 5.2 (Applied Biosystems). Negative controls were included in each extraction and PCR run to monitor for contamination, as well as a human DNA sample as PCR positive control. 
The sequences were aligned and compared with the species-specific $C y t B$ sequences available on GenBank ${ }^{\circledR}$ by using the BLAST (Basic Local Alignment Search Tool).

\section{Results and conclusion}

Single source mtDNA sequences were obtained from all four hair samples and data from negative and positive controls excluded exogenous DNA contamination.

The electropherograms of a forward and reverse reference sequence are given in Electronic Supplementary Material (ESM Fig. S1 and S2). All sequences were manually checked and consensus sequences were created (ESM Fig. S3).

BLAST alignment showed correspondence with both Canis lupus (accession code MK937053.1) and Canis lupus familiaris (accession code LR742875.1) mitochondrial genome, with an identity percentage of $99 \%$ for the hair entangled in the victim's paws and of $100 \%$ for the hairs found in the victim's mouth (ESM Fig. S4 and S5). It has to be noted that this mtDNA region is very well preserved and therefore identical between the sub-species Canis lupus (the wolf) and Canis lupus familiaris (the dog).

The results of the genetic analysis cleared foxes and nutrias as suspects, contrarily to the initial hypothesis. A wolf attack was considered very unlikely since wolves have never been reported in the area where the kill occurred. Besides, the type and the location of the wounds on the victim were inconsistent with the wolf killing pattern. The wolf is a specialized predator; its attack must be efficient, i.e. require as little energy as possible, and is usually aimed at eating. If the prey is small-sized, few, lethal wounds can be observed in the neck region of the animal and the carcass can be partially or entirely eaten. On the contrary, dogs lack the necessary experience for learning hunting techniques and predatory behaviour, which has a significant self-rewarding component. Consequently, a dog attack is characterized by the presence on the victim of numerous, non-lethal wounds all over the victim's body: ears, face, neck, thorax, flanks, lateral and ventral abdomen, inguinal region, limbs, tail. Given the lower dog bite power, many bites result in contusions that can only be detected after skinning as sub-dermal haemorrhages and suffusions. Moreover, lacerations and tearing injuries due to the prey's attempts to wriggle away are not uncommon and the carcass is not eaten [37].

Hence, we supposed that the attack was attributable to one or more medium- to large-sized dogs.

Performing canine STRs on swabs collected around the bitemarks would have been ideal to allow us to identify not only the species, but also the individual causing the bite marks. However, in this case, we were asked to intervene after the crime scene investigation and the carcass transfer to the diagnostic section; therefore, the carcass could have been exposed to external contamination. Even if we had sampled the areas around bite marks, we would not have had the certainty of the DNA source.

The morpho-metric features of the hairs collected from the victim's oral cavity and paws corresponded to the hair coat length and colour of the landowner's Hovawarts (black and gold, blond). This finding, together with the fact that the three Hovawarts were the only ones who had access to the property, pointed to them as prime suspects. In this specific case, we were not allowed to sample those dogs, and therefore, it was not possible to carry out further genetic investigations. Moreover, since the only reference sample in our possession consisted of shed hairs with no nuclear DNA, we could have only compared the mtDNA control region, whose exclusion capacity is, however, lower among dogs (normally ranging between 0.90 and 0.95$)$ than humans ( 0.995) and its discriminatory power restricted if compared with the genetic variation of nuclear DNA [19, 33, 38].

Notwithstanding these limitations, the cytochrome $b$ gene analysis alone allowed us to unmask a false wild animal attack, thus putting the case in an entirely different perspective.

Acknowledgements Open access funding provided by Alma Mater Studiorum - Università di Bologna within the CRUI-CARE Agreement.

Authors' contributions Conceptualization: Mariana Roccaro, Angelo Peli; formal analysis and investigation: Carla Bini, Giuseppe Merialdi, Susi Pelotti; writing - original draft preparation: Mariana Roccaro; writing - review and editing: Carla Bini, Paolo Fais, Susi Pelotti, Angelo Peli; resources: Giuseppe Merialdi, Susi Pelotti; supervision: Angelo Peli, Susi Pelotti.

Data availability The datasets used and/or analysed during the current study are available from the corresponding author on reasonable request.

\section{Compliance with ethical standards}

Conflict of interest The authors declare that they have no conflict of interest.

Ethics approval Not applicable.

Consent to participate Not applicable.

Consent for publication The dog's owner has consented to the submission of the case report to the journal.

Open Access This article is licensed under a Creative Commons Attribution 4.0 International License, which permits use, sharing, adaptation, distribution and reproduction in any medium or format, as long as you give appropriate credit to the original author(s) and the source, provide a link to the Creative Commons licence, and indicate if changes were made. The images or other third party material in this article are included in the article's Creative Commons licence, unless indicated otherwise in a credit line to the material. If material is not included in the article's Creative Commons licence and your intended use is not permitted by statutory regulation or exceeds the permitted use, you will need to obtain permission directly from the copyright holder. To view a copy of this licence, visit http://creativecommons.org/licenses/by/4.0/. 


\section{References}

1. Cassidy BG, Gonzales RA (2005) DNA testing in animal forensics. J Wildl Manag 69:1454-1462. https://doi.org/10.2193/0022541X(2005)69[1454:DTIAF]2.0.CO;2

2. Kanthaswamy S (2015) Review: domestic animal forensic genetics - biological evidence, genetic markers, analytical approaches and challenges. Anim Genet 46:473-484. https://doi.org/10.1111/age. 12335

3. Arenas M, Pereira F, Oliveira M, Pinto N, Lopes AM, Gomes V, Carracedo A, Amorim A (2017) Forensic genetics and genomics: much more than just a human affair. PLoS Genet 13:e1006960. https://doi.org/10.1371/journal.pgen.1006960

4. Menotti-Raymond MA, David VA, O'Brien SJ (1997) Pet cat hair implicates murder suspect. Nature 386:774. https://doi.org/10. $1038 / 386774 \mathrm{a} 0$

5. Giovambattista G, Ripoli MV, Lirón JP, Villegas Castagnasso EE, Peral García P, Lojo MM (2001) DNA typing in a cattle stealing case. J Forensic Sci 46:1484-1486. https://doi.org/10.1520/ JFS15176J

6. Caniglia R, Fabbri E, Greco C, Galaverni M, Randi E (2010) Forensic DNA against wildlife poaching: identification of a serial wolf killing in Italy. Forensic Sci Int Genet 4:334-338. https://doi. org/10.1016/j.fsigen.2009.10.012

7. Barrientos LS, Crespi JA, Fameli A, Posik DM, Morales H, Peral García P, Giovambattista G (2016) DNA profile of dog feces as evidence to solve a homicide. Legal Med 22:54-57. https://doi.org/ 10.1016/j.legalmed.2016.08.002

8. Schneider PM, Seo Y, Rittner C (1999) Forensic mtDNA hair analysis excludes a dog from having caused a traffic accident. Int $\mathrm{J}$ Legal Med 112:315-316. https://doi.org/10.1007/s004140050257

9. Brauner P, Reshef A, Gorski A (2001) DNA profiling of trace evidence-mitigating evidence in a dog biting case. J Forensic Sci 46:1232-1234

10. Tsuji A, Ishiko A, Kimura H, Nurimoto M, Kudo K, Ikeda N (2008) Unusual death of a baby: a dog attack and confirmation using human and canine STRs. Int J Legal Med 122:59-62. https://doi.org/10.1007/s00414-006-0150-6

11. Clarke M, Vandenberg N (2010) Dog attack: the application of canine DNA profiling in forensic casework. Forensic Sci Med Pathol 6:151-157. https://doi.org/10.1007/s12024-009-9114-8

12. Caniglia R, Fabbri E, Mastrogiuseppe L, Randi E (2013) Who is who? Identification of livestock predators using forensic genetic approaches. Forensic Sci Int Genet 7:397-404. https://doi.org/10. 1016/j.fsigen.2012.11.001

13. Caniglia R, Galaverni M, Delogu M, Fabbri E, Musto C, Randi E (2016) Big bad wolf or man's best friend? Unmasking a false wolf aggression on humans. Forensic Sci Int Genet 24:e4-e6. https://doi. org/10.1016/j.fsigen.2016.06.009

14. Eichmann C, Berger B, Reinhold M, Lutz M, Parson W (2004) Canine-specific STR typing of saliva traces on dog bite wounds. Int J Legal Med 118:337-342. https://doi.org/10.1007/s00414-0040479-7

15. Halverson JL, Basten C (2005) Forensic DNA identification of animal-derived trace evidence: tools for linking victims and suspects. Croat Med J 46:598-605

16. Berger B, Berger C, Hecht W, Hellmann A, Rohleder U, Schleenbecker U, Parson W (2014) Validation of two canine STR multiplex-assays following the ISFG recommendations for non-human DNA analysis. Forensic Sci Int Genet 8:90-100. https://doi.org/10.1016/j.fsigen.2013.07.002

17. de Pancorbo MM, Castro A, Fernández-Fernández I, GonzálezFernández MC, Martínez-Bouzas C, Cuevas N (2003) Cytochrome $\mathrm{b}$ and HVI sequences of mitochondrial DNA to identify domestic animal hair in forensic casework. Int Congr Ser 1239:841-845. https://doi.org/10.1016/S0531-5131(02)00592-7

18. Pfeiffer I, Völkel I, Täubert H, Brenig B (2004) Forensic DNAtyping of dog hair: DNA-extraction and PCR amplification. Forensic Sci Int 141:149-151. https://doi.org/10.1016/j.forsciint. 2004.01.016

19. Angleby H, Savolainen P (2005) Forensic informativity of domestic dog mtDNA control region sequences. Forensic Sci Int 154:99 110. https://doi.org/10.1016/j.forsciint.2004.09.132

20. Bekaert B, Larmuseau MHD, Vanhove MPM, Opdekamp A, Decorte R (2012) Automated DNA extraction of single dog hairs without roots for mitochondrial DNA analysis. Forensic Sci Int Genet 6:277-281. https://doi.org/10.1016/j.fsigen.2011.04.009

21. Parson W, Pegoraro K, Niederstätter H, Föger M, Steinlechner M (2000) Species identification by means of the cytochrome $b$ gene. Int J Legal Med 114:23-28. https://doi.org/10.1007/ s004140000134

22. Hsieh HM, Chiang HL, Tsai LC, Lai SY, Huang NE, Linacre A, Lee JCI (2001) Cytochrome b gene for species identification of the conservation animals. Forensic Sci Int 122:7-18. https://doi.org/10. 1016/S0379-0738(01)00403-0

23. Bravi CM, Lirón JP, Mirol PM, Ripoli MV, Peral García P, Giovambattista G (2004) A simple method for domestic animal identification in Argentina using PCR-RFLP analysis of cytochrome b gene. Legal Med 6:246-251. https://doi.org/10.1016/j. legalmed.2004.06.003

24. Pepe T, Trotta M, di Marco I, Cennamo P, Anastasio A, Cortesi ML (2005) Mitochondrial cytochrome b DNA sequence variations: an approach to fish species identification in processed fish products. J Food Prot 68:421-425. https://doi.org/10.4315/0362-028x-68.2. 421

25. Lee JCI, Tsai LC, Liao SP, Linacre A, Hsieh HM (2009) Species identification using the cytochrome $\mathrm{b}$ gene of commercial turtle shells. Forensic Sci Int Genet 3:67-73. https://doi.org/10.1016/j. fsigen.2008.10.005

26. Dawnay N, Ogden R, McEwing R, Carvalho GR, Thorpe RS (2007) Validation of the barcoding gene COI for use in forensic genetic species identification. Forensic Sci Int 173:1-6. https://doi. org/10.1016/j.forsciint.2006.09.013

27. Mitani T, Akane A, Tokiyasu T, Yoshimura S, Okii Y, Yoshida M (2009) Identification of animal species using the partial sequences in the mitochondrial 16S rRNA gene. Legal Med 11:S449-S450. https://doi.org/10.1016/j.legalmed.2009.02.002

28. Sarri C, Stamatis C, Sarafidou T, Galara I, Godosopoulos V, Kolovos M, Liakou C, Tastsoglou S, Mamuris Z (2014) A new set of 16S rRNA universal primers for identification of animal species. Food Control 43:35-41. https://doi.org/10.1016/j. foodcont.2014.02.036

29. Pereira L, Van Asch B, Amorim A (2004) Standardisation of nomenclature for $\operatorname{dog}$ mtDNA D-loop: a prerequisite for launching a Canis familiaris database. Forensic Sci Int 141:99-108. https://doi. org/10.1016/j.forsciint.2003.12.014

30. Eichmann C, Parson W (2007) Molecular characterization of the canine mitochondrial DNA control region for forensic applications. Int J Legal Med 121:411-416. https://doi.org/10.1007/s00414-0060143-5

31. Gundry RL, Allard MW, Moretti TR, Honeycutt RL, Wilson MR, Monson KL, Foran DR (2007) Mitochondrial DNA analysis of the domestic dog: control region variation within and among breeds. J Forensic Sci 52:562-572. https://doi.org/10.1111/j.1556-4029. 2007.00425.x

32. Baute DT, Satkoski JA, Spear TF, Smith DG, Dayton MR, Malladi VS, Goyal V, Kou A, Kinaga JL, Kanthaswamy S (2008) Analysis of forensic SNPs in the canine mtDNA HV1 mutational hotspot region*. J Forensic Sci 53:1325-1333. https://doi.org/10.1111/j. 1556-4029.2008.00880.x 
33. Himmelberger AL, Spear TF, Satkoski JA, George DA, Garnica WT, Malladi VS, Smith DG, Webb KM, Allard MW, Kanthaswamy S (2008) Forensic utility of the mitochondrial hypervariable region 1 of domestic dogs, in conjunction with breed and geographic information*. J Forensic Sci 53:81-89. https://doi.org/ 10.1111/j.1556-4029.2007.00615.x

34. Thai QK, Chung DA, Tran H-D (2017) Canis mtDNA HV1 database: a web-based tool for collecting and surveying Canis mtDNA HV1 haplotype in public database. BMC Genet 18. https://doi.org/ 10.1186/s12863-017-0528-0

35. Linacre A, Gusmão L, Hecht W, Hellmann AP, Mayr WR, Parson W, Prinz M, Schneider PM, Morling N (2011) ISFG: recommendations regarding the use of non-human (animal) DNA in forensic genetic investigations. Forensic Sci Int Genet 5:501-505. https:// doi.org/10.1016/j.fsigen.2010.10.017

36. Jehaes E, Gilissen A, Cassiman JJ, Decorte R (1998) Evaluation of a decontamination protocol for hair shafts before mtDNA sequencing. Forensic Sci Int 94:65-71. https://doi.org/10.1016/ s0379-0738(98)00052-8

37. Fico R, Angelucci S, Patumi I (2005) Accertamento dei casi di predazione sul bestiame domestico: metodi, validazione dei risultati e implicazioni gestionali. Lupo o cane: chi è stato? (Livestock predation assessment: methods, validation and management outcome. Wolf or dog predation: who did it?). Biol Cons Fauna 115:52-63

38. Budowle B, Wilson MR, DiZinno JA, Stauffer C, Fasano MA, Holland MM, Monson KL (1999) Mitochondrial DNA regions HVI and HVII population data. Forensic Sci Int 103:23-35. https://doi.org/10.1016/S0379-0738(99)00042-0

Publisher's note Springer Nature remains neutral with regard to jurisdictional claims in published maps and institutional affiliations. 